\title{
Barents Sea Geology, Petroleum Resources and Commercial Potential
}

\author{
A.G. DORÉ ${ }^{1}$
}

(Received 26 August 1993; accepted in revised form 22 March 1994)

\begin{abstract}
Geologically, the Barents Sea is a complex mosaic of basins and platforms. It underwent intracontinental sedimentation from about 240 million years ago to the early Cenozoic, about 60 million years ago, after which it bordered the developing Atlantic and Arctic oceans.

Geophysical investigations began during the 1970s, and the first offshore drilling occurred in the early 1980s. In Norwegian waters, drilling has proven 260-300 billion cubic meters of gas, with minor oil. Most of the reserves are contained in Jurassic sandstones. Exploration problems include the predominance of gas over oil and leakage of hydrocarbons from traps in recent geological time; both are connected with the intense erosion of the Barents Shelf that took place during the Cenozoic. Exploration efforts currently focus on new targets in areas such as the Finnmark Platform, the Nordkapp Basin, the Western Margin, and the area between $74^{\circ} 30^{\prime} \mathrm{N}$ and Spitsbergen. Oil accumulations have been discovered in Russian waters offshore from the TimanPechora Basin. However, major sedimentary basins west of Novaya Zemlya have yielded the most significant results. The largest finds include the Stokmanovskaya and Ludlovskaya supergiant gas fields. Stokmanovskaya alone has gas reserves in the order of 2500 billion cubic meters. Seismic surveys have documented a large inventory of untested structures, and further resources are probably present in the disputed area between Norwegian and Russian waters.

Options for commercial development of both Norwegian and Russian discoveries are currently being evaluated. These include the possible export of liquefied natural gas from the Norwegian Snøhvit Field to the European market. A consortium has carried out feasibility studies on the Russian Stokmanovskaya Field, and gas export solutions are being evaluated. In general, economic exploitation is hindered by the low price of natural gas, the distance to potential markets, difficult logistics, restricted drilling seasons and environmental concerns.
\end{abstract}

Key words: Arctic Ocean, Barents Sea, hydrocarbon potential, natural gas, Russia, Norway

RÉSUMÉ. Du point de vue géologique, la mer de Barents est une mosaïque complexe de bassins et de plates-formes. Elle a subi une sédimentation intracontinentale depuis il y a près de 240 millions d'années jusqu'au cénozoïque inférieur, il y a environ 60 millions d'années, après quoi, elle a bordé les océans Atlantique et Arctique en formation.

Des recherches géophysiques ont débuté au cours des années 1970, et le premier forage en mer a eu lieu au début des années 80. Dans les eaux norvégiennes, le forage a révélé des réserves prouvées de 260 à 300 milliards de mètres cubes de gaz, contenant un peu de pétrole. La plupart des réserves sont renfermées dans des grès du jurassique. La prédominance du gaz par rapport au pétrole et la dispersion d'hydrocarbures à partir de pièges formés au cours d'une période géologique récente comptent parmi les problèmes liés à l'exploration; ils sont tous deux reliés à l'érosion intensive de la plate-forme de Barents qui a eu lieu au cours du cénozoïque. Les efforts d'exploration portent actuellement sur de nouvelles cibles telles que la plate-forme du Finnmark, le bassin du NordKapp, la marge occidentale, ainsi que la zone située entre $74^{\circ} 30^{\prime}$ de latitude N. et le Spitzberg. On a découvert des gisements de pétrole dans les eaux russes, au large du bassin de Timan-Petchora. Mais ce sont les bassins sédimentaires à l'ouest de la Nouvelle-Zemble qui ont donné les résultats les plus probants. Parmi les grandes découvertes, on compte les très vastes gisements de gaz de Stokmanovskaya et de Ludlovskaya. Celui de Stokmanovskaya renferme à lui seul des réserves de gaz de l'ordre de 2500 milliards de mètres cubes. Des relevés sismiques ont attesté l'existence de nombreuses structures non explorées, et d'autres ressources se trouvent probablement dans la région contestée située entre les eaux russes et les eaux norvégiennes.

Des options visant l'exploitation commerciale des découvertes norvégiennes comme russes sont actuellement à l'étude. Elles comprennent l'exportation éventuelle du gaz naturel liquéfié du gisement norvégien de Snøhvit vers le marché européen. Un consortium a réalisé des études de faisabilité sur le gisement russe de Stokmanovskaya, et des solutions à l'exportation du gaz sont en cours d'évaluation. De manière générale, l'exploitation économique est freinée par le faible prix du gaz naturel, l'éloignement des marchés potentiels, une logistique difficile, des saisons de forage restreintes et des préoccupations environnementales.

Mots clés: océan Arctique, mer de Barents, potentiel en hydrocarbures, gaz naturel, Russie, Norvège

Traduit pour la revue Arctic par Nésida Loyer.

${ }^{1}$ Conoco Norway Inc., P.O. Box 488, 4001 Stavanger, Norway; present address: Statoil U.K. Ltd., Swan Gardens, 10, Piccadilly, London W1V 9LA, England

(C) The Arctic Institute of North America 


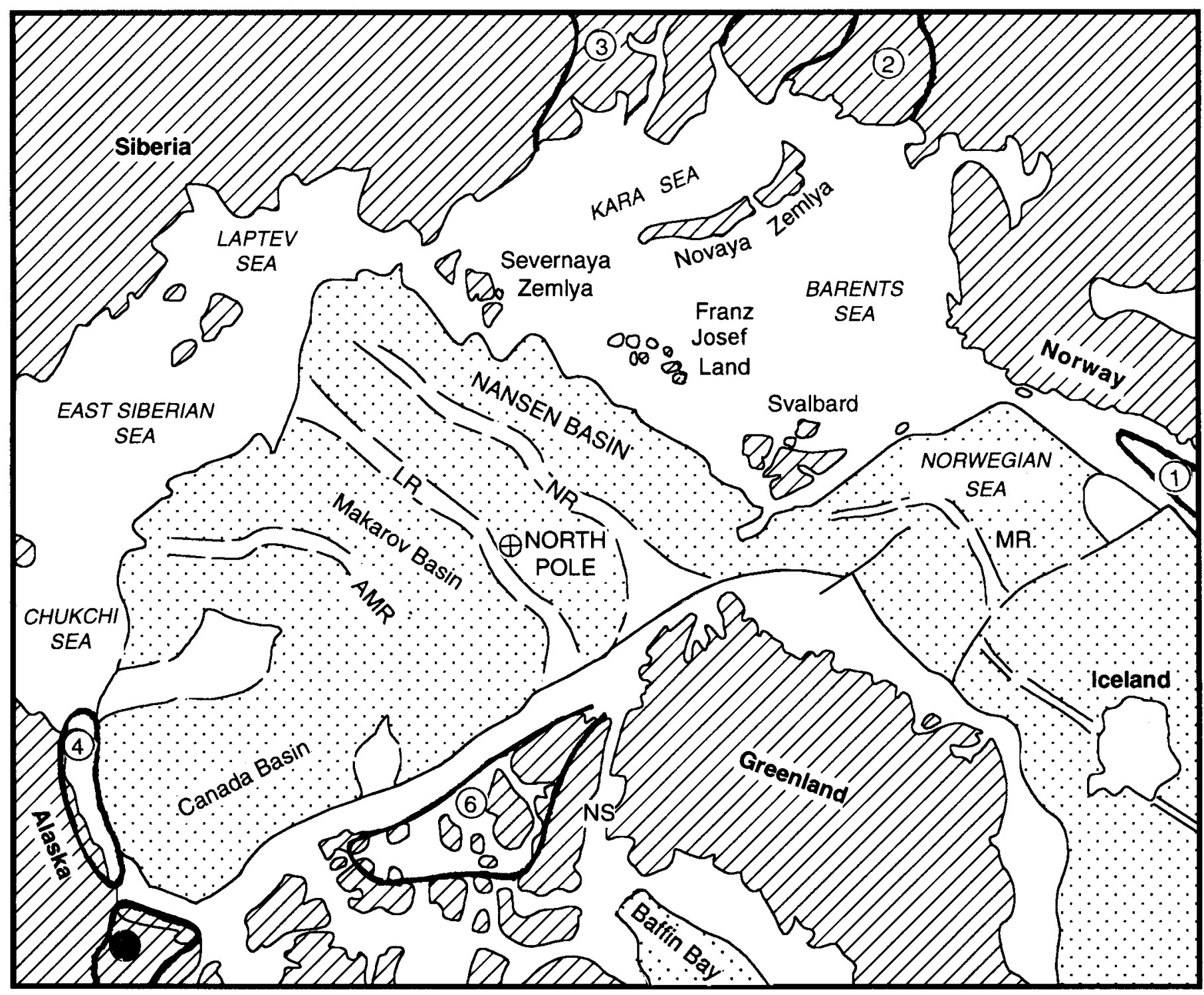

(1) MID-NORWEGIAN BASINS

(4) NORTH SLOPE OF ALASKA

(2) TIMAN-PECHORA BASIN

(5) MACKENZIE DELTA

(3) WEST SIBERIAN BASIN

(6) SVERDRUP BASIN

FIG. 1. Polar projection of the Arctic seas showing the ocean basins (stippled), the continental shelves (unshaded) and the relationship of the Barents Sea to other proven petroleum provinces. $A M R=$ Alpha-Mendeleyev Ridge, $L R=$ Lomonosov Ridge, $M R=$ Mohns Ridge, NR = Nansen Ridge, NS = Nares Strait.

\section{INTRODUCTION}

Physiographically, the Barents Sea is the region bracketed by the north Norwegian and Russian coasts, the Novaya Zemlya, Franz Josef Land and Svalbard archipelagos, and the eastern margin of the deep Atlantic Ocean. This defines an area of about 1.3 million $\mathrm{km}^{2}$. With water depths averaging about $300 \mathrm{~m}$, it is one of the largest areas of continental shelf on the globe. The portion of Norwegian Barents Sea currently open for hydrocarbon exploration, alone, covers 230000 $\mathrm{km}^{2}$-more than one and a half times the area of the Norwegian sector of the North Sea (Larsen et al., 1993). The Barents Sea is surrounded by a circumpolar chain of known petroleum basins, including the North Sea/Mid-Norwegian Shelf, the Sverdrup Basin and Mackenzie Delta of Arctic Canada, the North Slope of Alaska, the Western Siberian Basin and the Timan-Pechora Basin (Fig. 1). This simple geographical association makes the Barents Sea an obvious target for hydrocarbon exploration.

This paper illustrates aspects of the physical setting and commercial potential of the area, thereby providing a background for the multidisciplinary papers featured in this thematic set. Subjects covered include the generalities of Barents Sea geology, the search for hydrocarbons in the area, and the possibilities for commercial hydrocarbon exploitation. The paper is a distillation of published 


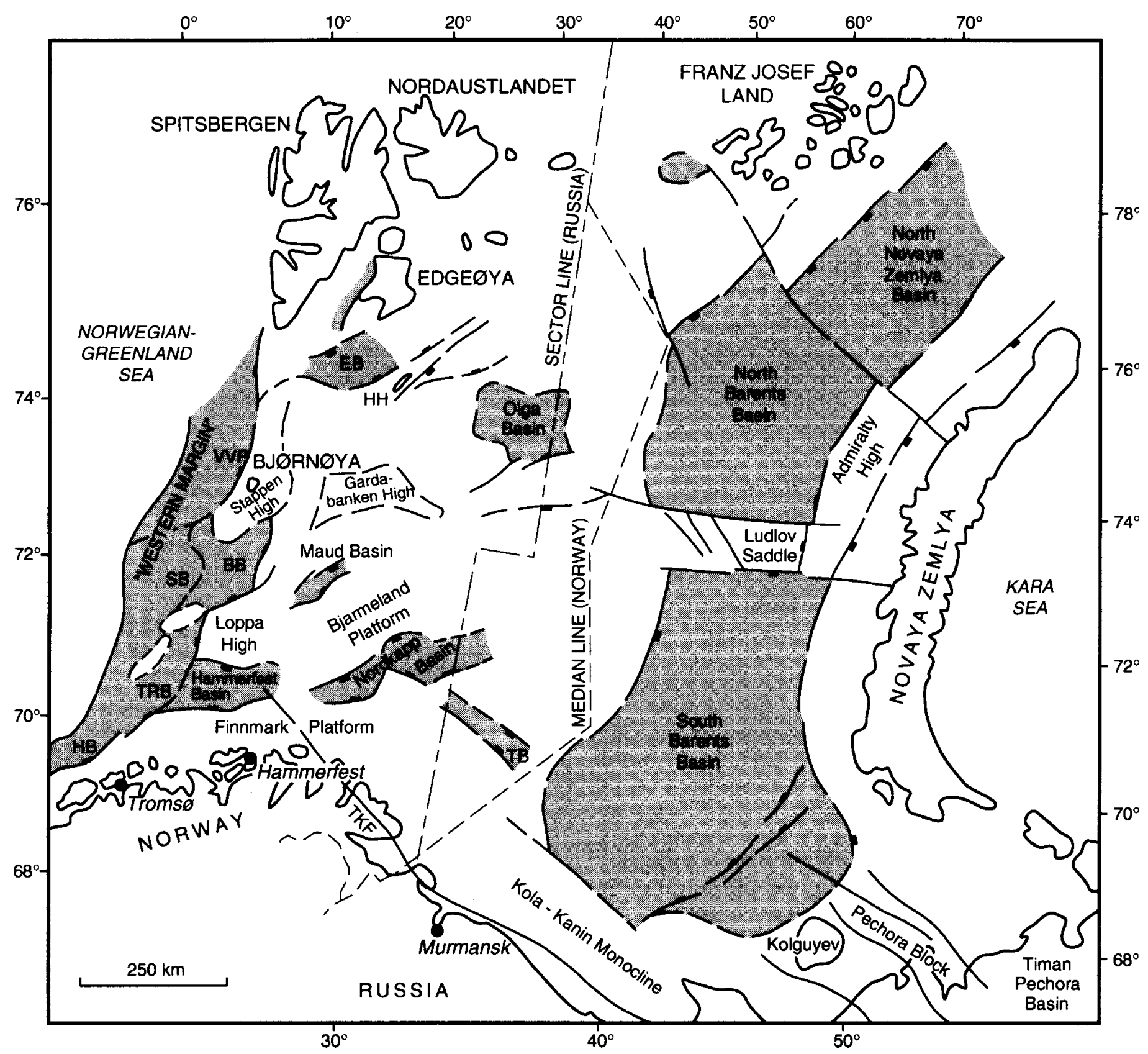

FIG. 2. Location map of the Barents Sea, showing the principal structural features. Sedimentary basins are shaded. BB = Bjørnøya Basin, EB = Edgeøya Basin, HB = Harstad Basin, HH = Hopen High, SB = Sørvestsnaget Basin, TB = Tiddlybanken Basin, TKF = Trollfjord-Komagelv Fault Zone, TRB = Troms $\emptyset$ Basin, VVP = Vestbakken Volcanic Province.

information on the Norwegian and Russian Barents Sea, drawing in addition on the large exploration database (principally well and seismic data) available to the companies active in the area. Observations on the western part of the Barents Sea-essentially the Norwegian sector-are better constrained than those on the eastern (Russian) portion because of better data availability and quality. The vastness of the Barents Sea and the concomitant volume of associated literature ensure that only the essential issues can be covered here. The reader is, however, directed toward sources of additional information on important topics.

\section{SUMMARY OF BARENTS SEA GEOLOGY}

The Barents Sea consists of a complex mosaic of platform areas and basins (Fig. 2), originally formed by two major continental collisions and subsequently sundered by continental separation. The first collision event, the Caledonian orogeny (mountain-building episode), culminated approximately $400 \mathrm{Ma}$ (million years ago). It represented the closure of the Iapetus Ocean, a major seaway occupying a position similar, but somewhat oblique to, the present northeast Atlantic. This collision resulted in the consolidation of the Laurentian plate (Greenland, North America) and the Baltic plate 
(Scandinavia, western Russia) into the Laurasian continent. The eastern margin of the Barents Sea was, from a geological standpoint, created by a further collision between the Laurasian continent and Western Siberia, culminating approximately $240 \mathrm{Ma}$ in the latest Permian-earliest Triassic. The Urals mountain chain and its northern extension, Novaya Zemlya, mark the suture zone of this closure. The Uralian orogeny was a final element in the fusion of most of the world's landmasses into a single supercontinent, Pangea, in PermianTriassic times (Scotese, 1987).

Caledonian and Uralian trends dominate the basement substructure of the Barents Sea (Doré, 1991; Johansen et al., 1993). Caledonian influences are seen in the N-S structural grain of the western Barents margin and Svalbard, and the NE-SW grain of the southwestern Barents Sea and Finnmark. The major basins of the Russian Barents Sea parallel the $\mathrm{N}-\mathrm{S}$ Uralian grain of the Novaya Zemlya chain.

The Late Palaeozoic and Mesozoic tectonic history of the Barents Sea was dominated by extensional tectonic movements, at first representing the collapse of the newly formed Caledonian and Uralian orogenic belts, and later due to stages in the progressive break-up of the Pangean supercontinent. Such episodes are recorded in the Early-Middle Devonian, Carboniferous, Permian, Triassic and late Jurassic-Early Cretaceous, and varied in significance according to location (Gramberg, 1988; Johansen et al., 1993). These events created the major rift basins traversing the Barents Shelf, and the intervening series of platforms and structural highs.

While deposition of a continental nature took place locally during the late Palaeozoic and early Mesozoic in the syn- and post-orogenic collapse basins, marine sedimentation was by far the dominant factor from the late Palaeozoic to the present day (Heafford, 1988). The marine depositional environment was strongly influenced by the specific tectonic setting, but also by climatic factors. The Barents Sea area drifted northwards from a paleolatitude of $20^{\circ} \mathrm{N}$ in the Carboniferous to $55^{\circ} \mathrm{N}$ in the Triassic, and from then on progressively to its present position of about $75^{\circ} \mathrm{N}$ (Worsley and Aga, 1986; Heafford, 1988). Thus carbonate deposition (with some important evaporite intervals) prevailed over wide areas of the shelf in Devonian, Carboniferous and Permian times; from the Triassic onwards, however, clastic (sand-shale) deposition under more temperate conditions was dominant.

Fragmentation of Pangea to form new continental masses and ocean basins began, locally, in the Early Cretaceous with the spreading of the Canada and Makarov basins of the Arctic Ocean. Opening of the Nansen Basin, with the separation of the Lomonosov Ridge continental slice from the Barents margin north of Spitsbergen (Fig. 1), probably began in the latest Cretaceous approximately $68 \mathrm{Ma}$. Spreading in the Norwegian Sea, between Norway and Greenland, is thought to have commenced in the Early Cenozoic about $60 \mathrm{Ma}$ (see Rowley and Lottes [1988], for the most complete reconstruction of the opening history of the Arctic Ocean and the adjacent Norwegian Sea). A north-south shear zone developed between north Greenland and the western margin of the Barents Shelf, forming a relay system between the Arctic and
Atlantic spreading centres (Doré, 1991). A transition to passive continental drifting between North Greenland and the Barents margin, and initiation of the Arctic-Atlantic oceanic connection, probably took place in mid-Cenozoic (Oligocene) times (Myhre and Eldholm, 1988).

\section{Principal Structural Features}

As shown in Figure 2, the most significant sedimentary basins, in terms of both thickness and areal extent, lie in the Russian sector immediately west of Novaya Zemlya. From north to south these are the North Novaya Zemlya Basin, the North Barents Basin and the South Barents Basin. They formed in the foredeep zone to the Uralian tectonic belt, and acted as major catchment areas for sediments shed from the Urals in late Palaeozoic-Mesozoic times (Gramberg, 1988). Up to $12 \mathrm{~km}$ thickness of Permian and younger sediments are present in these basins. Particularly impressive is the thickness of Triassic deposits, locally $6-8 \mathrm{~km}$. The line of basins terminates in the southeastern Barents Sea, where pre-Permian rocks rise in the subsurface to about $2-3 \mathrm{~km}$ deep. This area, essentially a structural continuation of the onshore TimanPechora Basin, is characterized by a NW-SE tectonic grain inherited from a Late Precambrian (Baikalian) tectonic episode.

Farther west the Nordkapp Basin, mainly within the Norwegian sector, is a half-graben (an elongate basin bounded by a major fault on one side) following a NE-SW Caledonoid trend. It was probably initiated by late Palaeozoic extension, and like the Russian basins was a major site of Triassic deposition (Jensen and Sørensen, 1992). It contains significant evaporite deposits of probable Late Carboniferous-Early Permian age, and the tectonics of axial portions of the basin are strongly dominated by halokinetic structures (salt domes and salt walls). The basin is bounded to the north and south by more stable platform areas, the Bjarmeland and Finnmark platforms respectively. Farther west, the Hammerfest Basin is an en echelon continuation of the Nordkapp Basin trend. The tectonic features of the basin observed today were essentially created by Late Jurassic-Early Cretaceous faulting. The Jurassic rocks that contain the bulk of the Norwegian hydrocarbon discoveries lie at a depth of approximately 2.5 $\mathrm{km}$ in the basin axis. The Hammerfest Basin is bounded to the north by the Loppa High, a positive tectonic element that was active in the Carboniferous and Permian and subsequently underwent frequent reactivations (Riis et al., 1986). West of a structural hinge line, the Ringvass $\varnothing y$-Loppa Fault Complex (Gabrielsen et al., 1990), lies a north-south line of deep basins, the Troms $\varnothing$ and Bjørnøya Basins, that underwent rapid subsidence in Cretaceous times. Salt structures, probably emanating from deposits of a similar age to those of the Nordkapp Basin, are typical of the Troms $\varnothing$ Basin (Sund et al., 1986).

In the northern part of the Norwegian sector on the Svalbard Platform, Mesozoic rocks subcrop beneath the thin Quaternary sedimentary cover. The Stappen High on the western edge of the platform was deeply eroded in Cenozoic time, and on its subaerial expression (Bjørnøya [Bear Island]) rocks ranging in age from Precambrian to Triassic are exposed 
(Worsley and Aga, 1986). The western margin of the Barents Shelf bordering the continent-ocean transition (Fig. 2) is characterized by the effects of Cenozoic tectonics and sedimentation associated with the northeast Atlantic continental separation. Large thicknesses of Cenozoic sediments were deposited in this area both before and after the onset of passive continental drifting in the Oligocene (Johansen et al., 1993). The sediments were derived from uplift and erosion of the Barents Shelf immediately to the east. Several kilometers of sediments were probably removed from this area during the Cenozoic (Nyland et al., 1992). Erosion and redeposition are thought to have been particularly intense during the Pleistocene glaciations.

\section{HISTORY OF BARENTS SEA PETROLEUM EXPLORATION}

\section{Norway}

If the Svalbard archipelago is regarded as part of the Barents Sea geological regime, then it can be confidently stated that petroleum exploration began in this area in the early twentieth century. Early geological surveys of the islands identified oil seeps, and in 1926 the Store Norske Spitsbergen Kullkompani began to investigate the hydrocarbon potential of central Spitsbergen. The first exploration wells were drilled by Norsk Polarnavigasjon (1963) and the Amoseas Group (1965-66). To date fourteen wildcat wells have been completed. These wells reported frequent shows of oil and gas, but only minor producible gas has so far been found. Petroleum exploration with similarly disappointing results has also been carried out by Russian interests, who have the right to explore for minerals on Spitsbergen under the provisions of the Svalbard Treaty of 1920 (Fleischer, 1993).

From the evidence to date it must be assumed that potential exists for more substantial discoveries on Svalbard. Large areas of central Spitsbergen are still licensed to companies, the most active being the Store Norske/Norsk Hydro group. Exploration will continue to be hindered by widespread ice cover, by permafrost conditions, and by the restricted season available for drilling. A detailed description of petroleum exploration in Spitsbergen is given by Nøttvedt et al. (1993).

As a result of the numerous geological surveys conducted since the early part of the century, Svalbard served as a useful template for early exploration of the Barents Sea. In particular, the presence of thick sedimentary rocks of MesozoicCenozoic age in the archipelago led early workers to suspect that a similar succession could lie offshore. Thus Harland (1969:40) reasoned that, compared to Spitsbergen, "the Barents Shelf submarine surface ... is not at a lower level because of greater erosion. In these circumstances relatively more of the stratigraphic sequence may be preserved there than would otherwise be expected. This argument improves whatever petroleum prospects there may be in the Barents Shelf."

Such arguments, and the success of exploration drilling in the North Sea in the mid 1960s, encouraged the Norwegian authorities to begin geophysical investigations in the Barents Sea in 1969. Reflection seismic data acquired in the following few years confirmed the existence of thick sedimentary successions and delineated the main offshore sedimentary basins (Rønnevik et al., 1975). In the Norwegian sector, the most promising basins (the Hammerfest and Troms $\varnothing$ Basins in the southwestern Barents Sea) were targeted because they were believed to contain reservoir and source rocks similar to those that had proven prospective in North Sea exploration. Acreage was offered in this area and awarded to several companies in the Norwegian 5th Round in 1980. The first well (7120/12-1) was drilled the same year, and the first discoveries (the Alke and Askeladden gas fields) were made the following year (Westre, 1984).

Subsequently, acreage has been leased steadily to the companies in a series of concession rounds (Figs. 3 and 5). The largest award in terms of total concession area was made as part of Round 13 in 1991. The most recent concessions were allocated under Round 14 in 1993. Drilling activity has been maintained at a fairly low but stable level during this period. To date just over 50 wildcat/appraisal wells have been drilled, compared with the approximately 600 such wells drilled in the Norwegian North Sea (County Natwest Woodmac, 1992; Norwegian Petroleum Directorate, 1993). The most important discoveries were made in the early to mid 1980s. These comprise the Askeladden, North Albatross and Snøhvit Fields (Fig. 4), which contain predominantly gas in reservoir rocks of Middle Jurassic age. Various authorities place the currently discovered resources of the Norwegian Barents Sea in the region of 260-300 billion $\mathrm{Sm}^{3}$ (standard cubic metres) of gas. Nearly 100 billion $\mathrm{Sm}^{3}$ are contained in the largest discovery, the Snøhvit Field. Only minor amounts of oil have been discovered.

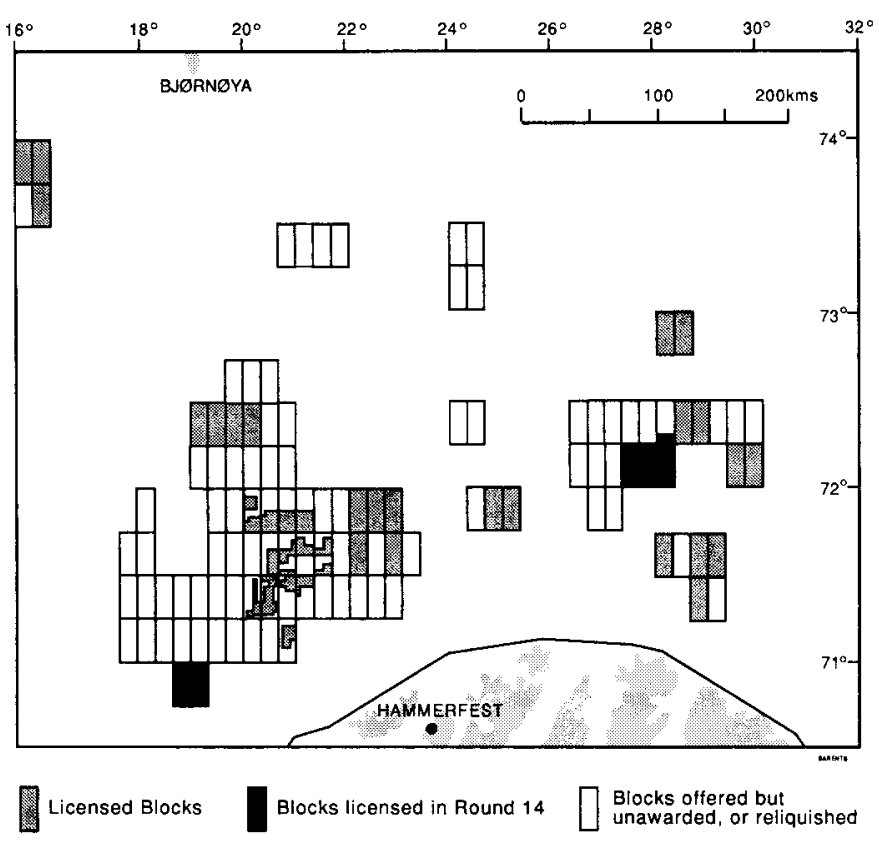

FIG. 3. Exploration acreage currently leased in the Norwegian Barents Sea, including that recently awarded in the 14 th concession round. 


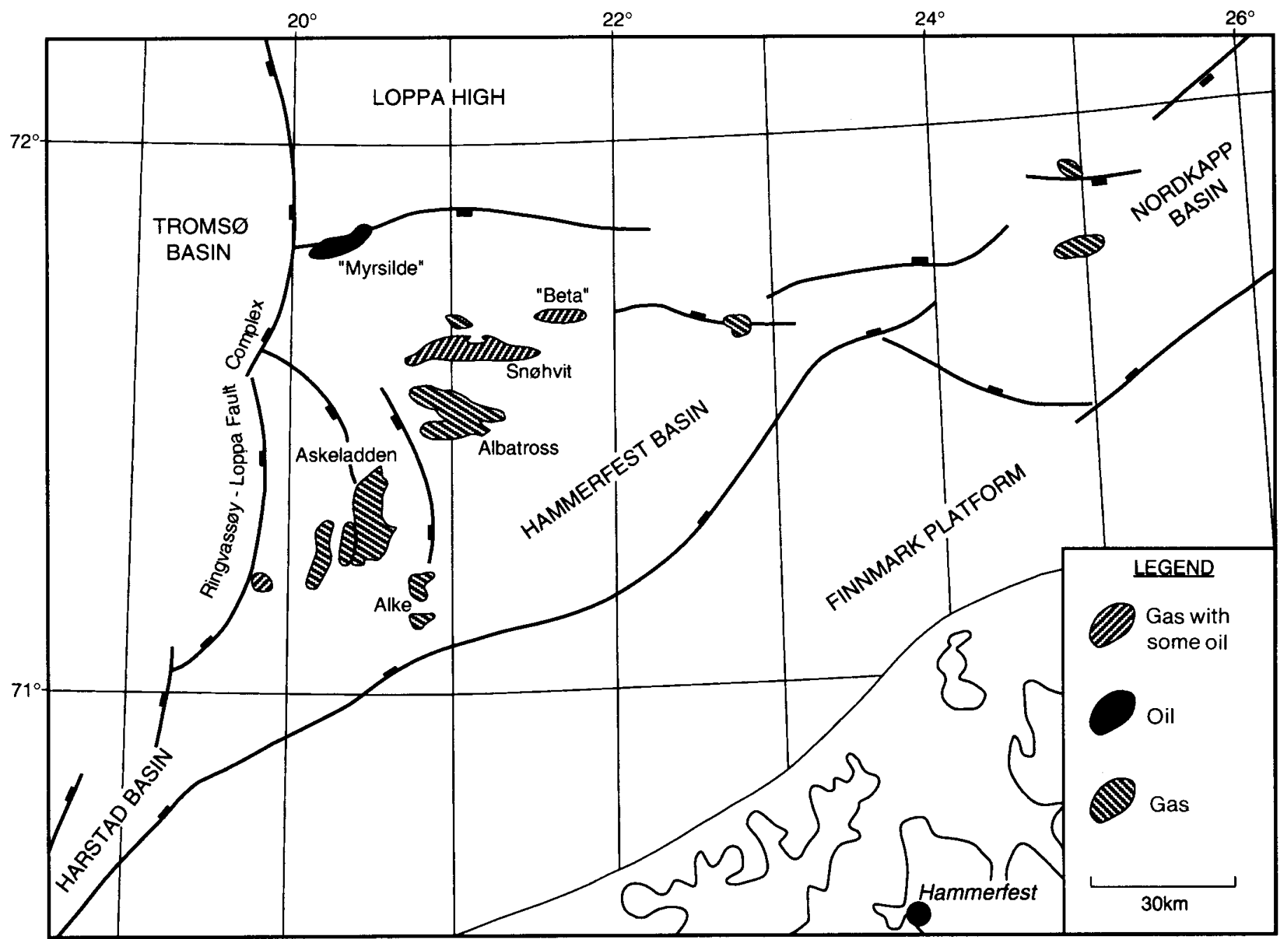

FIG. 4. Location map of oil and gas discoveries in the Norwegian Barents Sea. Modified after Larsen et al. (1993).

Exploration success rates in the Norwegian Barents Sea have been on average fairly high. Just over a third of all wildcat wells have encountered hydrocarbons capable of flowing to the surface (Norwegian Petroleum Directorate, 1993). There has, however, been a sharp decline in the discovery rate since the mid 1980s (Fig. 5). This marked change can be attributed to the early drilling of the most prospective structures in the Hammerfest Basin, and to the disappointing results from the subsequent testing of new exploration models. In the mid 1980s the Norwegian authorities took the decision to proceed with the selective leasing of concession blocks to the north and east of the Hammerfest Basin, sited to test new geological concepts in different structural settings. Significant tracts of acreage were awarded in Round 11 (1987), Round 12 (1989), Round 13 (1991) and Round 14 (1993) (see Fig. 5). Diverse reservoir targets of Carboniferous-Permian, Triassic, Jurassic, Cretaceous and Tertiary age were identified. To date only minor discoveries have been made, the latest being a probably subcommercial gas accumulation in the Sørvestnaget Basin (Fig. 2) in 1992.

\section{Russia}

In Russia, exploration success in the northern, coastal parts of the Timan-Pechora Basin provided a major incentive to extend the search offshore. Offshore research carried out in the 1960s-bathymetric, oceanographic and bottom sampling studies-established the probability that major sedimentary basins lay offshore. Extensive gravimetric, aeromagnetic and reflection seismic surveys were performed in the southern Barents Sea by Russian institutes during the 1970s, and by 1979 about twenty prospective structures had been identified, of which three were prepared for drilling (Ostisty and Fedorovsky, 1993).

Exploration drilling began in the early 1980s. The first discovery took place in 1982, when oil and gas were encountered in Triassic sandstones on Kolguyev island, and the accumulation was found to extend offshore. Later the same year, gas was discovered-again in the Triassic-in the Murmansk Field at the southern extremity of the South Barents Basin (Fig. 6). Since that time about 25 wells have been drilled in the Russian sector, and very significant hydro- 

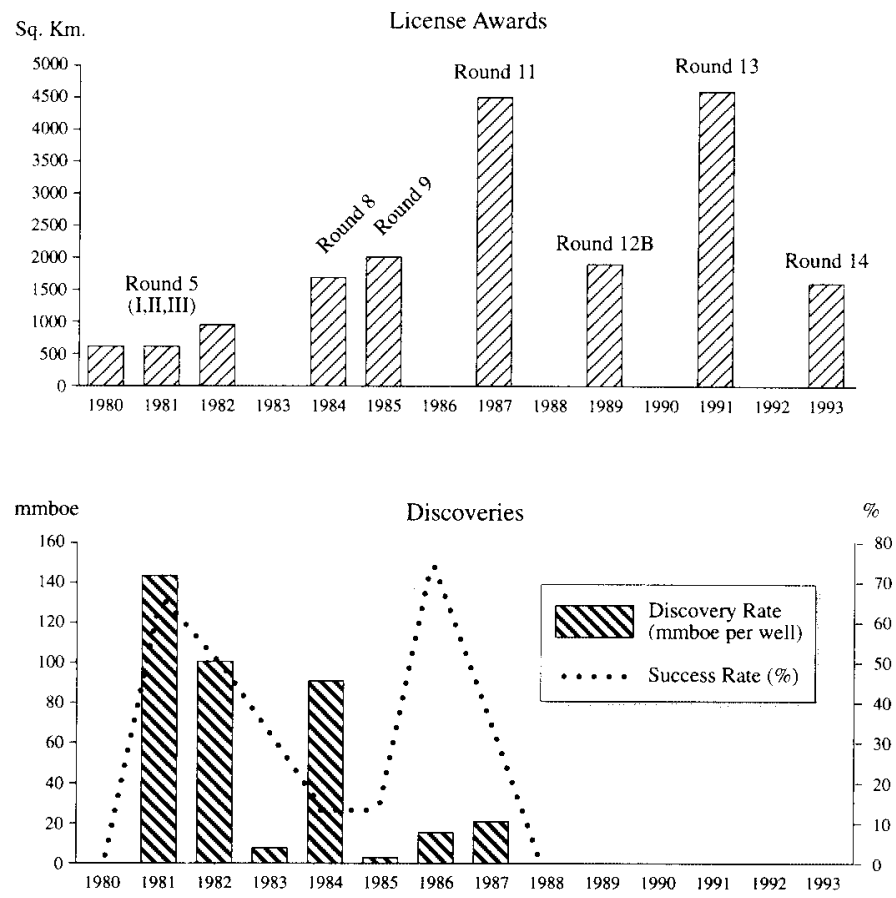

FIG. 5. Graphs for the Norwegian Barents Sea showing the progress of license awards (top) and the progress of discovery (bottom) to 1991. Redrawn and updated from County Natwest Woodmac (1992). The units quoted in the lower graph are millions of barrels of oil equivalent per well. This value is derived by dividing the total resources discovered by the number of exploration wells drilled over a given period, and is a measure of exploration success in a province. One barrel of oil is volumetrically equivalent to $0.159 \mathrm{Sm}^{3}$, and is the energy equivalent of approximately $1000 \mathrm{Sm}^{3}$ gas.

carbon finds have been made. The most spectacular of these is the Stokmanovskaya Field, discovered in 1988 in the northern part of the South Barents Basin. Stokmanovskaya contains gas and condensate in a reservoir consisting of Middle-Upper Jurassic marine sandstones. Its gas reserves are currently thought to be about 2500 billion $\mathrm{Sm}^{3}$ (County Natwest Woodmac, 1992). To put this figure into perspective, it compares in size to the supergiant Groningen Field of the Netherlands, is twice as large as Norway's largest gas field (Troll), and contains approximately eight times the total proven resources of the Norwegian Barents Sea. Other recent discoveries include Ludlovskaya, a similar structure to Stokmanovskaya and probably comparable in magnitude, and Prirazlomnoya, an oil field with a Carboniferous-Permian carbonate reservoir situated just offshore from the TimanPechora hydrocarbon province (Fig. 6).

On the basis of exploration results to date, the Russian sector can be crudely subdivided into two petroleum provinces: a southern, oil-prone region that is essentially a continuation of the onshore Timan-Pechora trend, and a much larger northern region west of Novaya Zemlya, where gas predominates.

\section{RESERVOIR ROCKS AND HYDROCARBON TRAPPING STYLES}

Figure 7 provides a summary by geological age of all reservoirs, proven and postulated, in the Barents Sea. The most significant proportion of the hydrocarbon resources proven to date in both the Norwegian and Russian Barents Sea is contained within strata of Jurassic age. The major discoveries in the Norwegian sector-Snøhvit, Albatross and Askeladden - all have a principal reservoir consisting of Lower-Middle Jurassic sandstone. This unit (the Stø Formation: see Dalland et al., 1988) was deposited in a coastal marine setting and, where penetrated in the Hammerfest Basin, usually has very favourable reservoir properties (high porosity and permeability). Larsen et al. (1993) estimate that about $85 \%$ of the Norwegian Barents Sea resources lie within this formation. Almost all of these resources are natural gas, the thin oil leg of the Snøhvit Field providing a minor exception (Fig. 8). In the giant Russian gas fields, Stokmanovskaya and Ludlovskaya, the principal reservoir is somewhat younger. Most of the resources are in marine sandstones of Upper Jurassic age, with subordinate amounts in the Middle Jurassic (Ostisty and Fedorovsky, 1993). The Stokmanovskaya gas is associated with significant quantities of condensate (light hydrocarbon liquids that condense out during gas production).

The traps that form the Norwegian Jurassic fields are generally fault-bounded positive blocks. In contrast, the Russian discoveries made to date appear to be in simpler dome-like structures. This is illustrated in Figure 8, which contrasts the principal fields in the two sectors (Snøhvit and Stokmanovskaya). In both cases the hydrocarbons are sealed by overlying Upper Jurassic shales.

Triassic and uppermost Permian sandstones contain fairly significant resources in the Russian Barents Sea. Discoveries include Murmanskaya (gas), North Kildinskaya (gas), and Pestchanoosjorsk on and offshore from the island of Kolguyev (oil and gas) (Fig. 6). The Triassic sediments were deposited in a series of deltas prograding westward from Novaya Zemlya, and as a consequence of this depositional environment, reservoir distribution is complex. Alternations of thin sandstones and shales are typical, and sand bodies are frequently discontinuous. Reservoir properties are generally not as favourable as those of the Jurassic. This situation also applies in the Norwegian sector, where the Triassic is generally even more sand-poor because of distance from source. To date, minor Triassic gas accumulations have been found in the Hammerfest Basin and on the margins of the Nordkapp Basin (Fig. 4). Triassic traps in both sectors include faultbounded and domal structures, and sealing is facilitated by intra-Triassic shales.

Palaeozoic rocks comprise the principal reservoirs of the onshore Timan-Pechora Basin. Oil and gas are found in sediments ranging in age from Ordovician to Permian. This province extends offshore into the southeastern Russian Barents Sea, where discoveries such as the Prirazlomnoya oil field (Fig. 6) have been made in Carboniferous and Permian carbonates (limestones and dolomites). Trapping is generally within bioherm structures (reef-like organic build-ups). Experience from the Timan-Pechora Basin and analogous areas worldwide shows that reservoir properties in such units are enhanced if the bioherm has been exposed subaerially and 


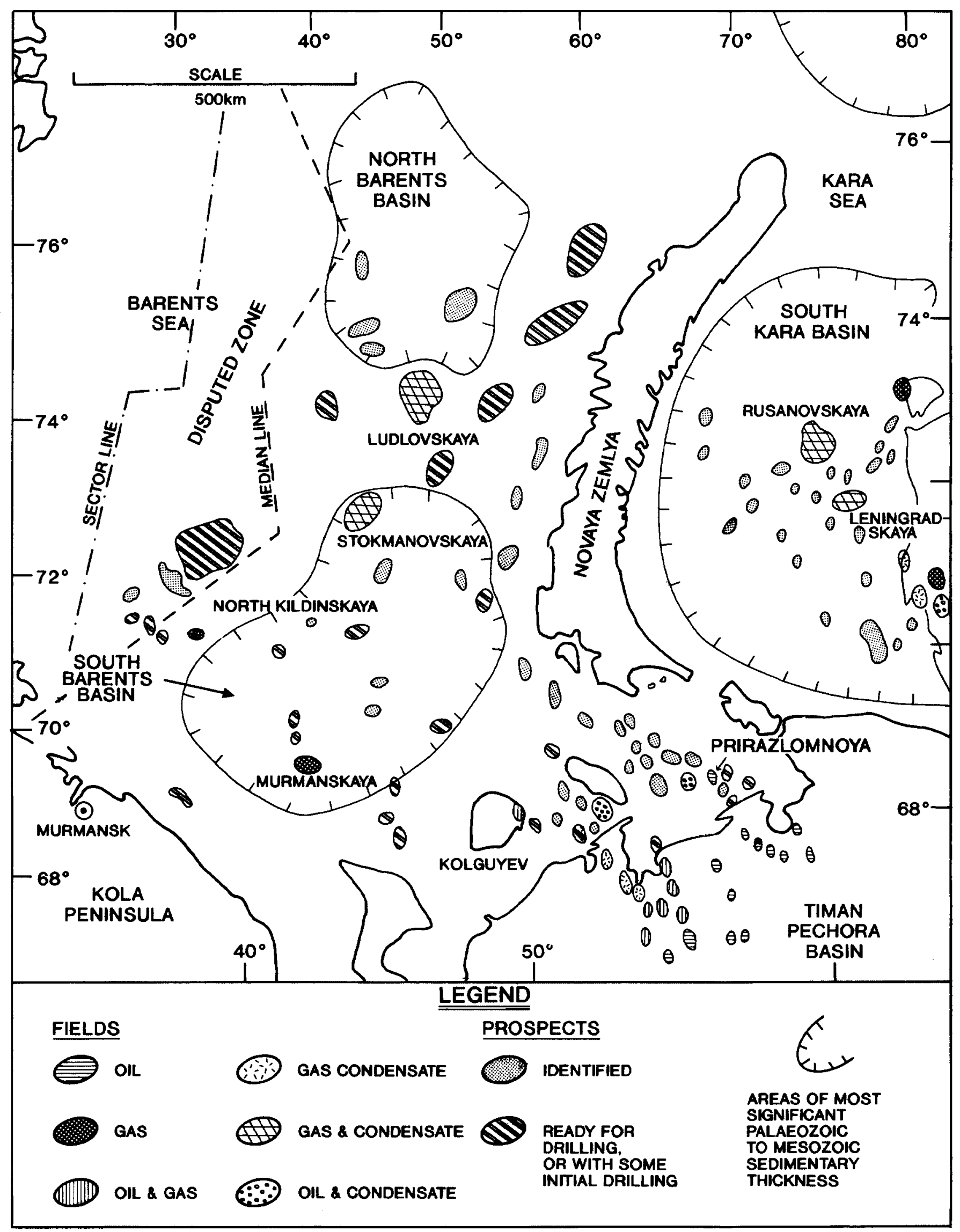



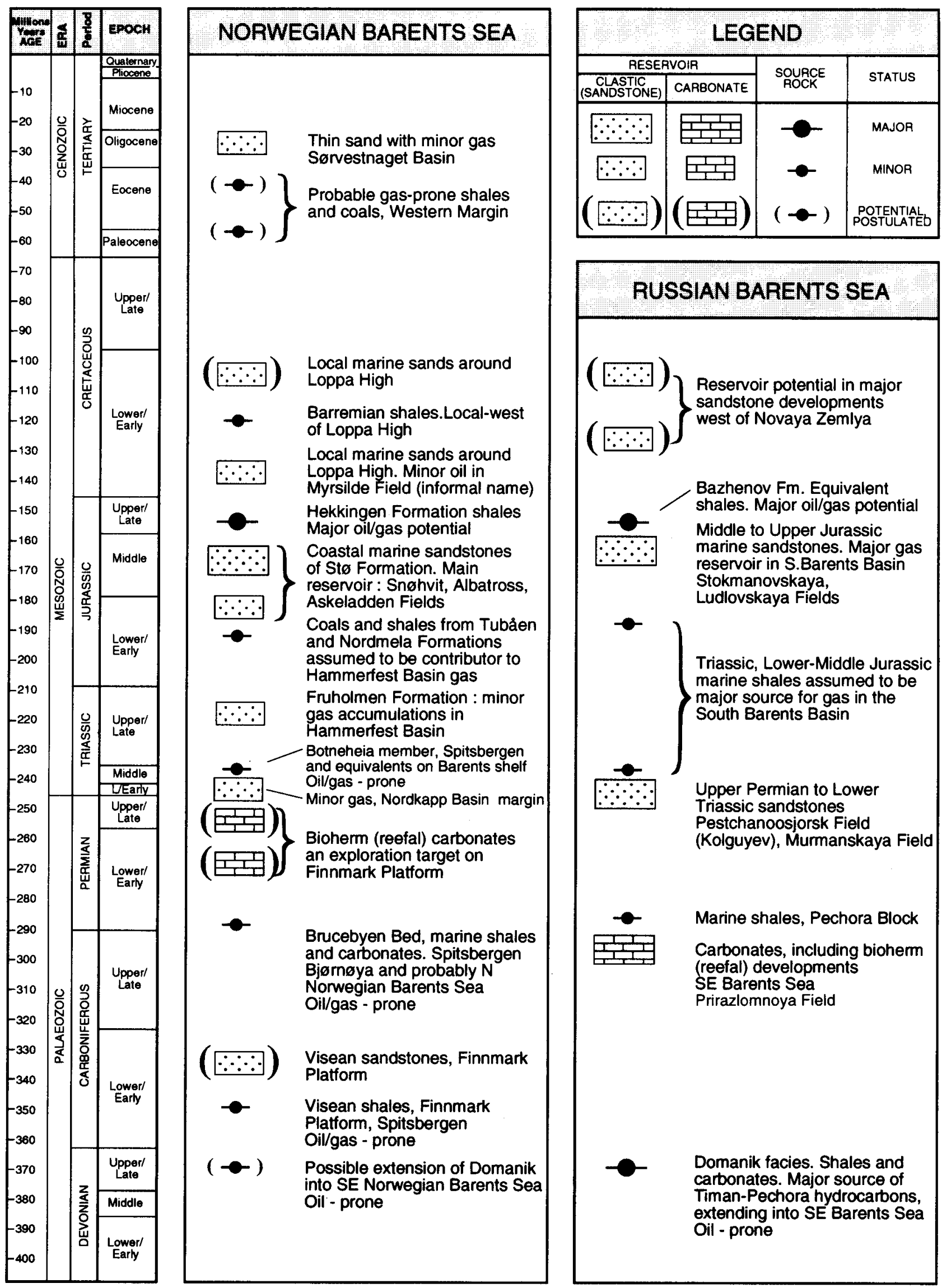

FIG. 7. Graphical summary of proven and potential reservoir and source rocks in the Barents Sea. The left-hand column shows the geological intervals referred to in the text and their approximate age. 
STOKMANOVSKAYA FIELD

(Russian Barents Sea)

Approx. Recoverable Reserves: $2500 \times 10^{9} \mathrm{Sm}^{3} \mathrm{Gas}$
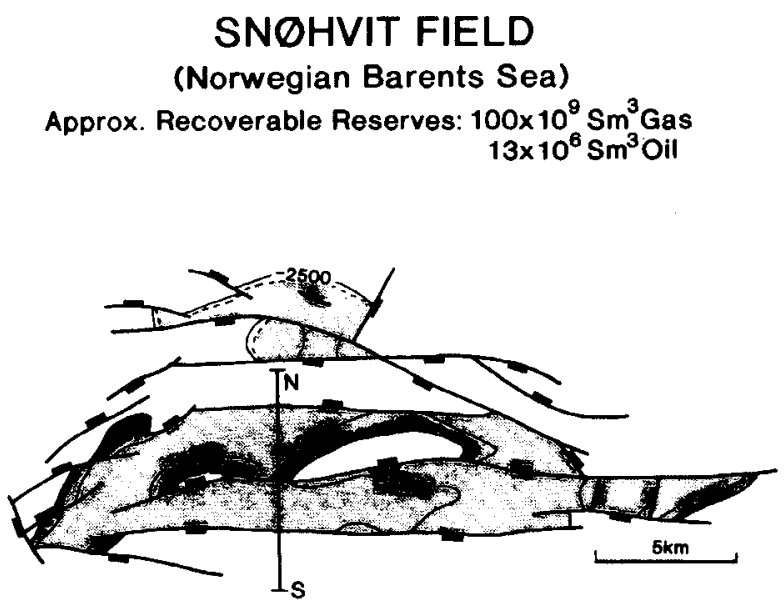

$\mathbf{s}$

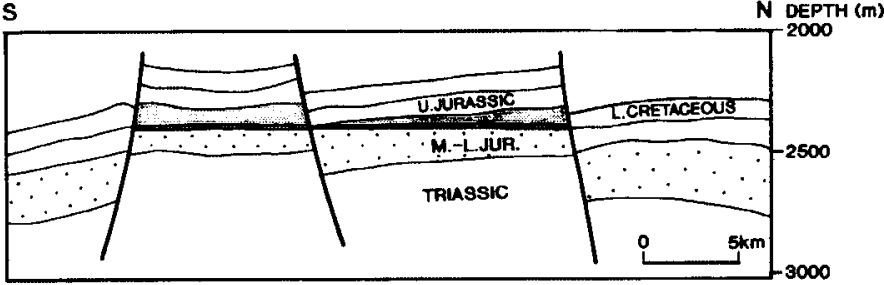

HYDROCARBON TYPE

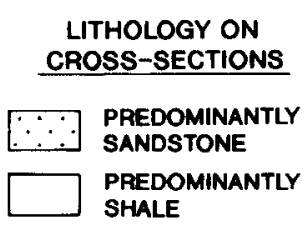

STOKMAN.

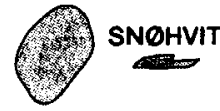

TRUE RELATIVE

AREAL SIZE

FIG. 8. Sketch maps and geological cross-sections of the Stokmanovskaya and Snøhvit Fields. The maps show contours of depth in metres below sea level to the top of the principal reservoir. Drawn from Ostisty and Fedorovsky (1993), Johansen et al. (1993) and in-house data.

undergone leaching by meteoric waters during the geological past (Wilson, 1975). Similar build-ups of Permian age have been observed on reflection seismic data extending westward into the Finnmark and Bjarmeland Platforms in the Norwegian sector (Bruce and Toomey, 1993). Drilling of one such feature by well 7128/6-1 (1991) found traces of oil, and further evaluation is under way at time of writing.

\section{SOURCE ROCKS}

The term "source rock," used in the oil industry, denotes a sedimentary unit capable of generating the hydrocarbons that subsequently migrate into a reservoir. A typical source rock contains greater-than-usual abundance of organic matter (kerogen) preserved by deposition in an environment that inhibits oxidation. Cracking of the kerogen to hydrocarbons takes place during burial and consequent heating, with oil forming at lower temperatures than gas. Terrestrial kerogen has a tendency to generate gas, whereas marine kerogen (e.g., algal material) is oil-prone.

Numerous potential source horizons are present in the Barents Sea (Fig. 7). The most widely distributed and best- quality unit consists of dark, organic rich shales and is of late Jurassic age. Closely equivalent shales provide the source for most of the hydrocarbons in the North Sea and mid Norway to the south, and in the West Siberian Basin to the east. In the Norwegian Barents Sea the unit is named the Hekkingen Formation (Dalland et al., 1988). Despite being widespread over most of the southern Barents Sea, these shales have not realized their full generation potential because of problems with maturity (i.e., having attained the right temperature to produce hydrocarbons). The unit is thought to be mature for oil and gas generation in a narrow belt at the western margin of the Hammerfest Basin and along the western fringe of the Loppa High. Farther west it is too deeply buried, and farther east it is too shallow. A portion of the hydrocarbons in the Hammerfest Basin accumulations was probably sourced from the Upper Jurassic, but some authorities (e.g., Larsen et al., 1993) believe that most of the discovered gas derives from underlying Lower Jurassic shales and coals. Much farther to the east, the Upper Jurassic may attain temperatures optimal for oil generation in parts of the North and South Barents Basins (Ostisty and Cheredeev, 1993).

The Middle Triassic Botneheia Member, a black phosphatic shale found on Spitsbergen, has long been known to be 
a potential source rock for oil and gas (Bjorøy et al., 1978). Drilling has identified equivalents of this unit in the southern Norwegian Barents Sea, where it is believed to be widespread but of very variable quality. The unit is probably mature for oil generation on many of the platform areas and gas-mature in the Hammerfest and Nordkapp Basins. Upper Triassic shales may also locally be of source quality in the Norwegian sector (Johansen et al., 1993). There is evidence that Triassic shales have sourced some of the Norwegian hydrocarbons, but a major contribution has not been proved.

Triassic source rocks are present at several horizons in the deep Russian basins west of Novaya Zemlya, and contain a significant proportion of terrestrial organic material due to proximity to the old Novaya Zemlya landmass. This factor, and the great burial depths, make the shale predominantly a gas source. The cumulative generation potential from the thick Triassic (and possibly Lower Jurassic) sedimentary pile is large, and it is widely assumed that the major gas discoveries of the South Barents Basin emanate from this source.

The significant hydrocarbon resources of the onshore Timan-Pechora Basin are largely derived from a much older source rock, the Domanik unit of Late Devonian to Early Carboniferous age (Ulmishek, 1982). The Domanik consists of dark marine shales and carbonates, and is a high-quality, oil-prone source rock. Sourcing of younger horizons from the Domanik occurred by means of vertical migration through faults. The unit extends offshore into the southeastern Barents Sea, where it is believed to have sourced some of the Russian oil and gas accumulations close to shore (Fig. 6). The economic importance of the Domanik unit has engendered much speculation as to whether it extends westward into the Norwegian sector. It has been suggested that the Devonian in this region, if present, will be developed in a less favourable terrestrial facies (Alsgaard, 1993). However, no Devonian rocks have been drilled and the case for source rocks of this age remains open.

\section{CURRENT EXPLORATION PROBLEMS AND FUTURE DIRECTIONS}

The most significant exploration problem in the Barents Sea, particularly relevant to the Norwegian sector, relates to the severe uplift and erosion of the area that took place during the Cenozoic. Residual oil columns found beneath gas fields in the Hammerfest Basin indicate that the structures were once filled, or partially filled, with oil. The removal of up to two kilometers of sedimentary overburden from the area comparatively late in geological time had severe consequences for these accumulations. Exsolution of gas from the oil, and expansion of the gas due to the decrease in pressure, resulted in expulsion of most of the oil from the traps. Seal breaching and spillage probably also occurred as a result of the uplift. A further consequence of these late movements was the cooling of the source rocks in the area, which effectively caused most hydrocarbon generation to cease. Thus, little new oil was available to fill available trapping space. These mechanisms explain the predominance of gas over oil in the Barents Sea (see Nyland et al., 1992, for a fuller description of this phenomenon).

Although the problems caused by Cenozoic uplift only became apparent during exploration of the Barents Sea in the mid 1980s, it is interesting to note that they were anticipated as early as 1904 by the great Norwegian explorer Fridtjof Nansen. Nansen (1904) postulated late uplift of the Barents Sea based on bathymetric observations taken during the Norwegian North Polar expeditions (1893-96). The relationship of Nansen's work to current Barents Sea thinking is discussed in more detail in Gabrielsen and Doré (in press), and an excellent description of his total contribution to arctic geology can be found in Hestmark (1991).

The apparent gas-prone nature of the Barents Sea is the primary reason for the slow pace of exploration in the area. Petroleum companies are essentially searching for oil, which is the economically more attractive phase. Recent exploration efforts have been directed toward locating traps in areas that may have been protected from severe uplift, or toward identifying traps that may have received remigrated oil evacuated from pre-existing accumulations.

\section{Future Targets}

Despite the difficulties outlined above, exploration of the Barents Sea is at an immature stage compared to that of other petroleum provinces worldwide, and very significant potential still exists. Exploration has been focused on only a few basins, and many of the structural units (Fig. 2) are undrilled or only sparsely drilled. Likewise, exploration has been directed toward particular stratigraphic successions, while others are almost unevaluated. Some of the more promising of these units are listed in the graphical summary of Figure 7.

The Norwegian Petroleum Directorate (1993) estimates that about 930 billion $\mathrm{Sm}^{3}$ gas and 220 million $\mathrm{Sm}^{3}$ oil, or approximately four times the currently discovered resources, remain to be discovered in the part of the Barents Sea claimed by Norway. This estimate is, of course, associated with a wide spread of uncertainty. Because many of the obvious Jurassic potential traps have been drilled, much of this potential lies at other stratigraphic levels. Some indication as to the nature of these targets is given by recent drilling on currently leased acreage.

In the western part of the area, the Tertiary potential of the Western Margin has to date only been tested by a single well, which found gas in sands of Oligocene age. Although the reserves proven were small, this result at least demonstrated that hydrocarbons have been generated and trapped in the area. Potential may also exist in rocks of Cretaceous age, particularly around the flanks of the Loppa High, which was eroded and shed sands into surrounding basins in Cretaceous times. A small oil discovery in Lower Cretaceous marine sands, informally named the Myrsilde Field (Fig. 4), has been 
made on the southern flank of the Loppa High, and analogous traps probably exist.

In the eastern Norwegian Barents Sea, residual oil has been found by initial drilling in Permian carbonates on the Finnmark Platform (see section on Reservoir Rocks and Hydrocarbon Trapping Styles) and further exploration drilling could take place on the Round 13 acreage in this area in the next few years. Targets include other potential traps and stratigraphic levels within the Permian, and sandstones of Lower Carboniferous (Visean) age (Fig. 7). Similar plays probably exist on the Bjarmeland Platform, but greater depth of burial makes them less immediately attractive.

Six new Barents Sea concessions were awarded to two partnerships under the Norwegian 14th Round (Fig. 3). Two of the blocks are located in the Harstad Basin at the southwestern extremity of the Barents Sea (Fig. 2), along a possible continuation of the Hammerfest Basin Jurassic trend. The remaining four blocks center on the southwestern lobe of the Nordkapp Basin. Only three wells have been drilled to date on the flanks of the basin, and the axial parts are undrilled. Sands and possible source rocks within the thickly developed Triassic succession provide the primary exploration incentive in this area. A variety of potential trapping styles has been identified, associated in particular with the major salt structures (domes and walls) that dominate the basin (see for example Larsen et al., 1993).

A group of six companies is now pooling resources to assess the remaining potential in the Norwegian Barents Sea and to determine future exploration directions. This strategic alliance is a logical response to high exploration costs and unproven commercial potential, but it is an unprecedented step in Norway, where the formation of partnerships prior to licensing has previously been discouraged by the authorities.

In the near future, exploration interest will turn to the unleased area north of $74^{\circ} 30^{\prime} \mathrm{N}$. Preliminary surveys (reflection seismic and sea-bottom sampling) show that basal Jurassic, Triassic and older rocks outcrop on the seabed or lie beneath a thin Quaternary cover over most of this region. Exploration will therefore center on older reservoir targets, and source rocks of Permian, Carboniferous and (possibly) Devonian age must be envisaged for the hydrocarbon source. Seismic data were made available to the industry by the Norwegian Petroleum Directorate in 1992, and environmental impact studies on the area are expected to be completed in 1995. These timings suggest that concessions will be available under the 16th Norwegian licensing round, probably in 1997. Exploration of this area will be highly seasonal because of winter pack-ice. Although the yearly extent of the ice is variable, it generally reaches south to about $75^{\circ} \mathrm{N}$, with a maximum development in March. This will be a severe logistical constraint, and significant exploration incentives will therefore be required to justify the high cost of drilling the area.

To my knowledge, there are no published quantitative estimates of undiscovered resources in the Russian Barents Sea. However, the results of the limited drilling to date indicate that vast potential exists, particularly for the discov- ery of natural gas (Ostisty and Cheredeev, 1993). As shown in Figure 6, numerous untested structures have been identified, and many of these are classed as "ready for drilling."

The prospects identified in and on the flanks of the North and South Barents basins include Jurassic traps of the Stokmanovskaya type and some Triassic prospects. Considerable potential is also identified in the Lower Cretaceous, which forms the reservoir for the giant Rusanovskaya Field in the Kara Sea (Fig. 6) and which contains thick sand successions west of Novaya Zemlya. All of these units are likely to contain primarily gas and gas condensate generated from the deep basins.

Prospects in the southeast of the area lie along the trend from the Timan-Pechora Basin and the Prirazlomnoya Field (Fig. 6). Reservoir targets will be of Palaeozoic and Triassic age, and, by analogy with local discoveries, potential exists for both oil and gas.

\section{POLITICAL CONSIDERATIONS}

A long-standing dispute exists between the Norwegian and Russian governments as to the position of the boundary delimiting the economic exploitation rights of the two countries. The Norwegian boundary claim is founded on the Geneva Convention of 1958, which supports the Median Line concept - the principle of equidistance from sovereign coastal baselines. The Russian claim is based on a Soviet decree of 1926, which recognizes the Sector Line principle, i.e., that the boundary should follow a line extending northwards from the onshore border to the North Pole. The disputed or "grey" zone between these competing claims constitutes a vast portion of continental shelf: $175000 \mathrm{~km}^{2}$ or approximately one-seventh of the total area of the Barents Sea (Figs. 2 and 6). The hydrocarbon potential of the disputed zone is poorly understood, but is widely assumed to be significant because of its area and its proximity to known hydrocarbons in Russian waters. The Russian authorities have identified several large prospects within the zone (Fig. 6) and have drilled wells close to the median line. No acreage has yet been awarded in Norwegian waters close to the disputed area. A full description of international marine law and its application to the Barents Sea can be found in Fleischer (1993).

\section{COMMERCIAL FACTORS}

The cost of exploration in the Norwegian sector of the Barents Sea is considerably higher than for other parts of the Norwegian Shelf. This can be attributed to the following factors:

- The remoteness of the area. Although potential shorebase facilities exist on the mainland at Harstad, Troms $\emptyset$ and Hammerfest, these do not yet possess the sophisticated logistical support capabilities of the equivalent North Sea bases. Special efforts are therefore required by the companies to maintain a drilling operation in the area. 
- Climatic conditions. The harsh Arctic climate requires the use of expensive, specially adapted "fourth generation" drilling rigs. Year-round drilling may also be precluded by climate.

- The necessity for environmental precautions. As is amply illustrated elsewhere in this volume, the Barents Sea contains important fishing and fish spawning grounds, and is also regarded as one of the last major sanctuaries for wildlife such as sea birds and marine mammals. Environmentally sensitive sites abound on adjacent coasts. Concern over such factors has led to the adoption of exhaustive oil-spill contingency measures for recent drilling. For example, the recent 7128/6-1 Round 13 well, drilled by Conoco $55 \mathrm{~km}$ from the Finnmark coast, required two standby boats and two oil-spill recovery vessels to be on 24-hour call. In addition, drilling seasons may be restricted to avoid fish-spawning periods. Thus, in recent drilling of Thirteenth Round acreage in the Sorvestnaget Basin (well 7316/5-1), a restriction was imposed whereby potential hydrocarbon-bearing levels could not be penetrated during the most sensitive period for fish eggs and larvae, July 1 to August 1.

The commercial development of hydrocarbon resources discovered in the area will also be subject to these factors, but must overcome further obstacles. Water depths in the principal Norwegian discovery area, the Hammerfest Basin, are in the order of $300 \mathrm{~m}$-deeper than those of average North Sea fields. Although such depths by no means preclude commercial development, they call for less conventional development schemes such as full subsea development, floating production systems or tension-leg platforms. North Sea fields can make cost savings by tie-in to existing production infrastructure, whereas the first Barents Sea developments would essentially require stand-alone economics. Finally, and most importantly, economics are hampered by distance to potential markets. Although significant gas reserves have been discovered, these resources could only reach the main European markets through a major commitment to pipeline building, or by transport as liquefied natural gas (LNG). These expensive solutions make Barents Sea gas uncompetitive in the European market, which is currently amply supplied by gas from sources closer to home such as the North Sea. Oil is more easily transported via offshore loading and tanker, but the minor quantities so far discovered do not justify development. Conceptual economics suggest that an oil field in the Norwegian Barents Sea would require recoverable reserves of about 50 million $\mathrm{Sm}^{3}$ (300 million barrels) to break even economically (e.g., County Natwest Woodmac, 1992).

The Snøhvit gas field, with its significant gas reserves and high-performance Jurassic reservoir, will be the first development in the Norwegian sector, barring more attractive discoveries in the near future. Development options recently evaluated by the operator, Statoil, are full subsea development with transport to shore via multiphase pipeline, and the use of a floating production system with gas and condensate pipelines to shore. The most likely option for transport and sale of the gas would be through liquefaction onshore and delivery to European markets by LNG tanker. A further, less likely option is to use the gas to drive a power station for supplying electricity to Finland. The latter scheme would not, however, utilize sufficient gas to satisfy the economic hurdle rate for field development. County Natwest Woodmac (1992) estimate that a gas price of $\$ 5.20$ per thousand cubic feet (1992 dollars) would be required for Snøhvit to break even economically using the LNG option, compared to $\$ 2.50$ for a gas field in the Norwegian North Sea. These factors suggest that, given current market projections, production of Snøhvit gas is unlikely before the turn of the century.

Reserves discovered in the Russian Barents Sea dwarf those of Norwegian waters. Gas fields such as Stokmanovskaya and Ludlovskaya contain resources comparable to those of the Western Siberian gas fields and, given the right conditions, would be capable of guaranteeing supplies to markets for half a century or more. Nevertheless, they suffer from the same economic constraints as their Norwegian counterparts-distance to market, harsh climatic conditions and environmental concerns. Development concepts for the Stokmanovskaya supergiant have recently been evaluated by a consortium of Russian, American, Norwegian and Finnish companies. Stokmanovskaya gas would most probably be transported by pipeline to feed the central European market. Once again, however, production is not expected before the turn of the century. Oil discoveries such as Prirazlomnoya, just offshore from the productive TimanPechora Basin, would also be logical candidates for exploitation in the relatively near future, but at time of writing no firm development plans are known to the author.

\section{CONCLUSIONS}

The Barents Shelf houses substantial reserves of natural gas. World-class gas fields have been proven in both the Norwegian and Russian sectors, with the Russian discoveries being particularly impressive. Despite some disappointments, the Barents Sea is only sparsely explored, and the overall expectation for hydrocarbon discoveries remains high.

The potential for discovery and possible development of petroleum reserves must, however, be seen against the background of the area's important marine resources and known environmental sensitivity. Public concern over conservation issues is shared by most oil company workers who, naturally, have no wish to see some recent, disastrous arctic oil spills repeated in the Barents Sea. During the 14th concession round (1993), a number of environmental pressure groups lobbied the Norwegian oil companies, urging them not to apply for Barents Sea acreage. They argued that the Barents Sea, as one of the few remaining areas of natural wilderness on the globe, should be left untouched by further industrial development.

In the short term it seems that this wish will be fulfilled, for economic rather than environmental reasons. As shown in earlier sections, the pace of exploration in the Barents Sea is comparatively slow, and commercial development of reserves 
is unlikely before the next century. In the longer term, however, this situation will change. At current rates of consumption, world oil reserves are expected to decline sharply by the middle of the 21st century (Campbell, 1991; Lerche 1992). Natural gas is more widespread and plentiful, but increased demand for this source of energy will soon deplete supplies close to the principal markets. Barring unforeseen geopolitical upheavals, attention will inevitably turn to logistically difficult areas such as the Barents Sea to meet global energy needs. Local political factors - for example, the desire to bring industrial development and livelihoods to remote areas such as northern Norway-could accelerate this process.

Thus, it is reasonable to speculate that by the year 2050 the Barents Sea will have developed into a major centre for commercial hydrocarbon exploration. Fifty years is a long time in terms of human foresight, but a short time in the life of a major marine ecosystem. Barents Sea explorers in the not-too-distant future will face many of the problems encountered today, and will have some tough decisions to make.

\section{ACKNOWLEDGEMENTS}

I am grateful to Aston Embry, Brian Harland and an anonymous reviewer for their helpful comments on the manuscript, and to Karen McCullough for good editorial handling. I also thank Knut Pedersen's drafting department at Conoco Norway Inc. for producing the text figures, and Mike Beling of Statoil U.K. Ltd. for additional graphics work. The opinions in this paper are my own and do not necessarily represent those of either of the companies I have worked for during its preparation.

\section{REFERENCES}

ALSGAARD, P.C. 1993. Eastern Barents Sea Late Paleozoic setting and potential source rocks. In: Vorren, T.O., Bergsager, E., Dahl-Stamnes, Ø.A., Holter, E., Johansen, B., Lie, E., and Lund, T., eds. Arctic geology and petroleum potential. Norwegian Petroleum Society (NPF) Special Publication 2. Amsterdam: Elsevier. 408-418.

BJORØY, M., VIGRAN, J.O., and RØNNINGSLAND, T.M. 1978. Source rock evaluation of Mesozoic shales from Svalbard. IKU (Continental Shelf Institute) Open Report 160/1/78. 214 p.

BRUCE, J.R., and TOOMEY, D.F. 1993. Late Palaeozoic bioherm occurrences of the Finnmark Shelf, Norwegian Barents Sea: Analogues and regional significance. In: Vorren, T.O., Bergsager, E., Dahl-Stamnes, Ø.A., Holter, E., Johansen, B., Lie, E., and Lund, T., eds. Arctic geology and petroleum potential. Norwegian Petroleum Society (NPF) Special Publication 2. Amsterdam: Elsevier. 377-392.

CAMPBELL, C.J. 1991. Golden century of oil, 1950-2050: The depletion of a resource. Dordrecht, Boston, London: Clair Academic Publishers. 345 p.

COUNTY NATWEST WOODMAC. 1992. Barents Sea Update. County Natwest Woodmac, Northwest Europe Report. Oil and Gas 76:4-14.
DALLAND, A., WORSLEY, D., and OFSTAD, K. 1988. A lithostratigraphic scheme for the Mesozoic and Cenozoic succession offshore mid- and northern Norway. Norwegian Petroleum Directorate Bulletin 4. 65 p.

DORÉ, A.G. 1991. The structural foundation and evolution of Mesozoic seaways between Europe and the Arctic. Palaeogeography, Palaeoclimatology, Palaeoecology 87:441-492.

FLEISCHER, C.A. 1993. International law and its application to the Arctic. In: Vorren, T.O., Bergsager, E., Dahl-Stamnes, Ø.A., Holter, E., Johansen, B., Lie, E., and Lund, T., eds. Arctic geology and petroleum potential. Norwegian Petroleum Society (NPF) Special Publication 2. Amsterdam: Elsevier. 721-731.

GABRIELSEN, R.H., and DORÉ, A.G. In press. The history of tectonic models on the Norwegian continental shelf. In: Hanslien, S. et al., eds. Petroleum exploration and exploitation in NorwayPast experiences and future challenges: A celebration of 25 years. Norwegian Petroleum Society (NPF) Special Publication 5. Amsterdam: Elsevier.

GABRIELSEN, R.H., FÆRSETH, R.B., JENSEN, L.N., KALHEIM, J.E., and RIIS, F. 1990. Structural elements of the Norwegian continental shelf. Part 1: The Barents Sea Region. Norwegian Petroleum Directorate Bulletin 6. 33 p.

GRAMBERG, I.S., ed. 1988. The Barents Shelf Platform. PGO Sevmorgeologia. Leningrad: Nedra. 263 p.

HARLAND, W.B. 1969. Mantle changes beneath the Barents Shelf. Transactions of the New York Academy of Sciences, Series II. 31(1):25-41.

HEAFFORD, A.P. 1988. Carboniferous through Triassic stratigraphy of the Barents Shelf. In: Harland, W.B., and Dowdswell, E.K., eds. Geological evolution of the Barents Shelf region. London: Graham and Trotman. 89-108.

HESTMARK, G. 1991. Fridtjof Nansen and the geology of the Arctic. Earth Sciences History 10(2):168-212.

JENSEN, L.N., and SØRENSEN, K. 1992. Tectonic framework and halokinesis of the Nordkapp Basin, Barents Sea. In: Larsen, R.M., Brekke, H., Larsen, B.T., and Talleraas, E., eds. Structural and tectonic modelling and its application to petroleum geology. Norwegian Petroleum Society (NPF) Special Publication 1. Amsterdam: Elsevier. 109-120.

JOHANSEN, S.E., OSTISTY, B.K., BIRKELAND, Ø., FEDOROVSKY, Y.F., MARTIROSJAN, V.N., BRUUN CRISTENSEN, O., CHEREDEEV, S.I., IGNATENKO, E.A., and MARGULIS, L.S. 1993. Hydrocarbon potential in the Barents Sea region: Play distribution and potential. In: Vorren, T.O., Bergsager, E., Dahl-Stamnes, Ø.A., Holter, E., Johansen, B., Lie, E., and Lund, T., eds. Arctic geology and petroleum potential. Norwegian Petroleum Society (NPF) Special Publication 2. Amsterdam: Elsevier. 273-320.

LARSEN, R.M., FJÆRAN, T., and SKARPNES, O. 1993. Hydrocarbon potential of the Norwegian Barents Sea based on recent well results. In: Vorren, T.O., Bergsager, E., DahlStamnes, Ø.A., Holter, E., Johansen, B., Lie, E., and Lund, T., eds. Arctic geology and petroleum potential. Norwegian Petroleum Society (NPF) Special Publication 2. Amsterdam: Elsevier. 321-331.

LERCHE, I. 1992. Oil exploration: Basin analysis and economics. San Diego: Academic Press Inc. and HBJ. 178 p. 
MYHRE, A., and ELDHOLM, O. 1988. The western Svalbard margin $\left(74-80^{\circ} \mathrm{N}\right)$. Marine and Petroleum Geology 5:134-156.

NANSEN, F. 1904. The bathymetrical features of the north polar seas, with a discussion of the continental shelves and previous oscillations of the shore-line. In: Nansen, F., ed. The Norwegian North Polar expedition 1893-1896. Scientific results IV(13). Christiania: Jacob Dybwad. 232 p.

NORWEGIAN PETROLEUM DIRECTORATE. 1993. Petroleum resources-Norwegian continental shelf. Stavanger: Norwegian Petroleum Directorate. 38 p.

NØTTVEDT, A., LIVBJERG, F., MIDBØE, P.F., and RASMUSSEN, E. 1993. Hydrocarbon potential of the Central Spitsbergen Basin. In: Vorren, T.O., Bergsager, E., DahlStamnes, Ø.A., Holter, E., Johansen, B., Lie, E., and Lund, T., eds. Arctic Geology and Petroleum Potential. Norwegian Petroleum Society (NPF) Special Publication 2. Amsterdam: Elsevier. 333-361.

NYLAND, B., JENSEN, L.N., SKAGEN, J., SKARPNES, O., and VORREN, T.O. 1992. Tertiary uplift and erosion in the Barents Sea: Magnitude, timing and consequences. In: Larsen, R.M., Brekke, H., Larsen, B.T., and Talleraas, E., eds. Structural and tectonic modelling and its application to petroleum geology. Norwegian Petroleum Society (NPF) Special Publication 1. Amsterdam: Elsevier. 153-162.

OSTISTY, B.K., and CHEREDEEV, S.I. 1993. Main factors controlling regional oil and gas potential in the West Arctic, former USSR. In: Doré, A.G. et al., eds. Basin modelling: Advances and applications. Norwegian Petroleum Society (NPF) Special Publication 3. Amsterdam: Elsevier. 591-597.

OSTISTY, B.K., and FEDOROVSKY, Y.F. 1993. Main results of oil and gas prospecting in the Barents and Kara Seas inspire optimism. In: Vorren, T.O., Bergsager, E., Dahl-Stamnes, Ø.A., Holter, E., Johansen, B., Lie, E., and Lund, T., eds. Arctic geology and petroleum potential. Norwegian Petroleum Society (NPF) Special Publication 2. Amsterdam: Elsevier. 243-252.

RIIS, F., VOLLSET, J., and SAND, M. 1986. Tectonic development of the western margin of the Barents Sea and adjacent areas. American Association of Petroleum Geologists Memoir 40. 661-676.

RØNNEVIK, H.D., BERGSAGER, E., MOE, A., ØVREBØ, O., NAVRESTAD, T., and STANGENES, J. 1975. The geology of the Norwegian continental shelf. In: Woodland, A.W., ed. Petroleum and the continental shelf of northwest Europe. Volume 1, Geology. London: Institute of Petroleum. 117-129.

ROWLEY, D.B., and LOTTES, A.K. 1988. Plate-kinematic reconstructions of the North Atlantic and Arctic: Late Jurassic to present. Tectonophysics 155:73-120.

SCOTESE, C.R., Coordinator. 1987. Phanerozoic plate tectonic reconstructions. Paleoceanographic mapping project, Institute of Geophysics, University of Texas Technical Report 90. Map portfolio.

SUND, T., SKARPNES, O., JENSEN, L.N., and LARSEN, R.M. 1986. Tectonic development and hydrocarbon potential offshore Troms, northern Norway. American Association of Petroleum Geologists Memoir 40. 615-627.

ULMISHEK, G. 1982. Petroleum geology and resource assessment of the Timan-Pechora Basin, USSR, and the adjacent BarentsNorthern Kara Shelf. Argonne National Laboratory, Report EES-TM-199. 197 p.

WESTRE, S. 1984. The Askeladd gas field-Troms 1. In: Spencer, A.M. et al., eds. Petroleum geology of the north European margin. London: Graham and Trotman. 33-39.

WILSON, J.L. 1975. Carbonate facies in geologic history. Berlin: Springer-Verlag. $471 \mathrm{p}$.

WORSLEY, D., and AGA, O.J., eds. 1986. The geological history of Svalbard. Stavanger: Statoil. 121 p. 